医機学 Vol.82, No. 4 (2012) ( 7 )

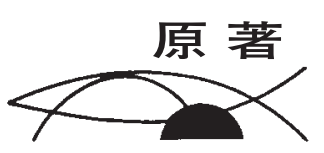

\title{
圧閉度制御によるフィンガポンプの流量特性改善に関する研究
}

\author{
澤 栁良 ${ }^{*}$ 堀 内 邦 雄 ${ }^{* 1}$
}

\section{A Study on Flow Quantity Characteristic Improvement in a Finger Pump by Occlusion Control}

\author{
Ryo Sawayanagi ${ }^{*}$ and Kunio Horiuchi ${ }^{* 1}$ \\ * Department of Mechanical Engineering, School of Engineering, \\ * Graduate School of Kogakuin University \\ * Department of Innovative Mechanical Engineering, \\ Faculty of Global Engineering, Kogakuin University
}

\section{Abstract}

Infusion pumps are used throughout hospitals as medical devices which can control the delivery of medicine to patients. However, infusion pumps often have problems related to the control of flow rate. Volumetric infusion pumps need to use a dedicated tube and restore force reduction in the tube for flow rate errors. In fact, infusion pump flow rate decreased by $1.14 \mathrm{~mL} / \mathrm{h}(4.56 \%)$ in a 12 hour experiment. Devised a system to improve flow rate error by restoring force reduction in the tube. Our objective is to show the efficacy of this device.

The method in this study increases inner pressure in a tube by using an occluder. This allows a constant liquid feed by the expansion of the tube.

This experiment used an infusion pump with a set flow rate $10 \mathrm{~mL} / \mathrm{h}, 25 \mathrm{~mL} / \mathrm{h}$ and $50 \mathrm{~mL} / \mathrm{h}$ of for 12 hours. Internal pressure of $290 \mathrm{kPa}$ was measured by the tonometori method, and occlusion degree pressure was controlled by an occluder. As a result, This method was able to deliver an improvement of $0.30 \mathrm{~mL} / \mathrm{h}, 0.71 \mathrm{~mL} / \mathrm{h}$ and $1.01 \mathrm{~mL} / \mathrm{h}$ over conventional methods.

It can be concluded that infusion pump flow rate error by restoring force reduction in the tube is improved by increasing inner pressure in the tube and was able to show the efficacy of device.

\section{1. 目 的}

輸液ポンプは，自然落下に頼らず，ポンプの 機械的な力を利用して, より正確な輸液をおこ なうものであり，効果の高い薬剤を微量かつ正

* 工学院大学大学院工学研究科機械工学専攻

*1 工学院大学グローバルエンジニアリング学部 機械創造工学科

(原稿受付: 2012 年 1 月 31 日)
確に投与する場合をはじめとしてさまざまな臨 床目的に使用される。このため輸液ポンプは, 病院内で多く使用される医療機器のひとつとな っている。しかし，まれに輸液バックの残量と， 輸液ポンプの積算量に違いが起こる事例が報告 されている ${ }^{1,2)}$.これらの問題の多くは看護師 によるヒューマンエラーが関係しているが, 輸液セットや装置の問題もある 子.4 $^{3.4}$.

ペリスタルティック方式輸液ポンプは, 点滴 
筒の落下数を滴下センサでカウントして適 正な流量にコントロールする滴下制御方式と, 専用のチューブを用い, 設定した流量に対応し たチューブ変形を与え, 一定の送液を可能にす る容積制御方式がある ${ }^{5)}$. 前者のポンプは専用 の輸液セットを用いなくてもよいが, 薬液の表 面張力や密度による滴下数変化が流量の誤差 となる ${ }^{5,6)}$. 後者のポンプは, 薬液の種類に影 響されないが輸液セットを最適でない状態 でセットした場合や, 輸液チューブ（以下, チューブ）の復元力の低下による断面積の減少 が流量誤差の原因となり, 製品仕様書に記載され ている $\pm 10 \%$ を越える可能性が報告されてい る $^{7 \sim 9)}$.

設定流量 $25 \mathrm{~mL} / \mathrm{h}$ で容積制御方式輸液ポン プを 12 時間稼働させ, 流量変化を調査したと ころ, 送液開始に対し終了時での流量減少量は $1.14 \mathrm{~mL} / \mathrm{h} \quad(4.56 \%)$ であった。輸液ポンプを 長時間使用することで, チューブが変形するこ とが報告されていることから ${ }^{9)}$, 送液の減少は チューブ変形およびチューブ復元力の低下によ るものであると考えられる.

容積制御方式輸液ポンプのチューブ復元力 の回復を促すため, フィンガ部出口からオク ルーダまでのチューブ内圧（以下，チューブ 内圧）を上昇させ，チューブ変形を復元させ るための圧閉機構を組み込んだ輸液ポンプを 考案した. 本研究は考案した機構の機能を評価 し，有効性を示すことを目的とする.

\section{2. 方 法}

考案した圧閉機構を評価するため, 図 1 に示 す圧閉度制御装置を試作した。図 1 の装置は, フィンガポンプ機構の下部に試作した圧力計と オクルーダをセットし, オクルーダでチューブ の流路抵抗を増加させ, チューブ内圧を上昇さ せる構造である.フィンガポンプ機構には閉塞 検出機構を取り外した輸液ポンプ STC-508 (TERUMO 社) を用いた. フィンガの1 ス卜 ローク内で変動するチューブ内圧を 2.1）章で 示す圧力計で測定した．オクルーダを駆動する リニアアクチュエータはフィンガの 1 ストロー ク内で変動するチューブ内圧の最大值（以下,

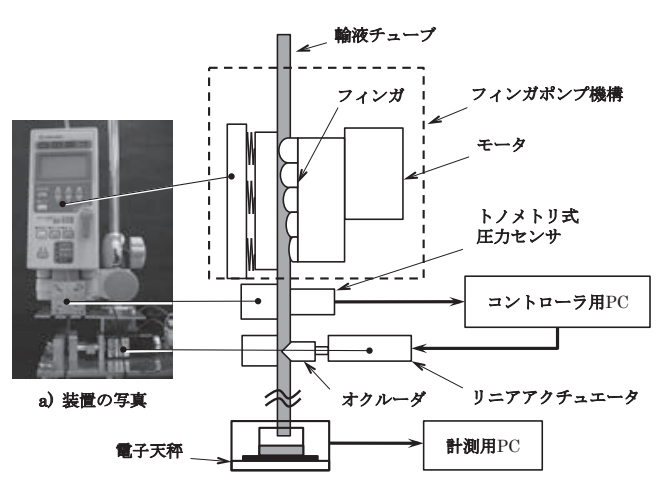

b) 装置の模式図

図 1 圧閉度制御装置を組み付けた輸液ポンプ および流量測定システム

最大内圧值）を基に制御した.

\section{1 ) チューブ内圧測定装置の試作と評価}

輸液ポンプは閉塞センサを用いてチューブ内 圧測定をおこなっているが，本研究では圧閉度 制御をおこなう上で, 精度が高く, 液体に非接 触なチューブ内圧測定を必要とした。そこで非 侵襲で血圧を測定するためなどに用いられてい るトノメトリ法を用いた。 トノメトリ法は橈骨 動脈などの表在した動脈を体表面から平らに圧 迫すると，圧迫された部分の動脈上では血管内 圧と血管を圧迫する圧力が一致するという原理 である。したがって，この部分に圧力計を置け ば，血管外から間接的に血圧を検出できる方法 である ${ }^{10,11)}$ 。この原理を用い, チューブ内圧を 測定する装置を試作した（以下，トノメトリ式 圧力計). 圧力の測定実験には輸液セット TS-PA 200 L 037 （TERUMO 社）とロードセ ル LMA-A- $5 \mathrm{~N}$ (共和電業社) を用いた。 図 2 に示すように外径 $4.5 \mathrm{~mm}$ のチューブ中心をロー ドセルの上に乗せ, チューブの外径を $2.3 \mathrm{~mm}$ まで押し潰し扁平部を形成した。

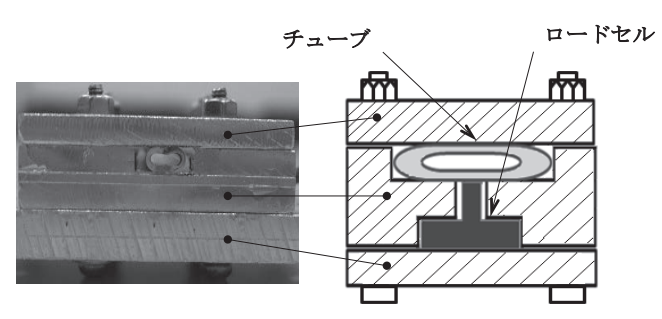

a)下面からの写真模式橉

図2トノメトリ式圧力計の構造 
トノメトリ式圧力計で測定したチューブ内圧 值と, チューブ内を直接測定したチューブ内圧 值との相関関係を確認した。直接測定には圧力 トランスデューサAP-13S（KEYENCE 社） を用い, トノメトリ式圧力計との高さを合わ せ，チューブに水を満たした状態で 0 補正し た.チューブの出口を閉塞し, 輸液ポンプの設 定流量を $25 \mathrm{~mL} / \mathrm{h}$ で稼働させ, 直接測定の数 值が $230 \mathrm{kPa}$ を示すまでコンピュータで圧力と ロードセル出力電圧を同時計測した.

\section{2）圧閉度制御装置の試作と流量精度 の評価}

実験は図 1 に示すトノメトリ式圧力計とオク ルーダを装着した構造の装置を用いた。オク ルーダはリニアアクチュエータ DRL 28 PA 1 G$03 \mathrm{~N}$ (オリエンタルモータ社) と連結した構造 となっており, チューブの圧閉度を制御する。 リニアアクチュエータは 1 パルス当り $0.4 \mu \mathrm{m}$ 移動するものであり, 最大内圧值が制御值より 高い場合はチューブ圧閉度を緩める方へ, 制御 值がー $20 \mathrm{kPa}$ より小さい場合はチューブを圧 閉する方へオクルーダを動作させた．また，測 定開始 10 分から測定終了 120 分までの最大内 圧值を $1 \mathrm{kHz}$ でサンプリングし, 実際にコント ロールされた最大内圧值の平均值と $95 \%$ の信 頼区間を算出した。

流量精度評価方法は日本工業規格 JIS T 0601 2-24（以下, JIS 規格）に記載されている, ボ ルメトリック形輸液コントローラ, ボルメト リック形輸液ポンプおよびシリンジポンプの 正確度試験に従った ${ }^{12)}$ 。実験は空調のある実 験室でおこない, 実験開始時に気温と湿度を記 録した。サンプル抽出間隔 $S[\mathrm{~min}]$ で i 回目の 測定における質量サンプル $W[\mathrm{mg}]$, を電子天 秤 GH-252（A \& D 社）で測定, 試験液の温度 $t$ における密度 $d_{t}[\mathrm{~g} / \mathrm{mL}]$ から 1) 式で実測流量 $Q_{i}[\mathrm{~mL} / \mathrm{h}]$ を算出した。試験液の温度は実験室 の気温と同じと仮定した.

$Q_{i}=\frac{60\left(W_{i}-W_{i-1}\right)}{S d_{t}}$

輸液ポンプ機構は STC-508 (TERUMO 社) の閉塞検出機構を取り外したものを用い, サ ンプル抽出間隔 $S=0.5 \mathrm{~min}$ とし, 試験液は
純水装置（MILLIPORE 社）で作成した純水を 用いた．測定時間は長期的な変化を知るため 6 時間とした. スタートアップカーブは 37 デー 夕 (18.5 min) の実測流量の移動平均で示し た。また, 流量減少量は 37 デー夕の移動平均 したグラフの測定開始から 2 時間の最大值と測 定終了時の 30 分間の最小值の実測流量の差か ら求めた。

最良となる最大内圧值の範囲を決定すること を目的とし最大内圧值を変化させた場合の 流量変化の測定をおこなう。輸液ポンプの 設定を中間流量の $25 \mathrm{~mL} / \mathrm{h}$ とし, オクルーダ を用いない従来の $0 \mathrm{kPa}$ と最大内圧值を 140 , 220，290 および $300 \mathrm{kPa}$ に設定し流量を測定し た.

また, 看護師が夕方に稼働させ, 早朝に確認 することを仮定し，12 時間連続使用における 流量変化を測定した. 最大内圧值は効果が得 られる上限の $290 \mathrm{kPa}$ とした。輸液ポンプの設 定流量は $10 \mathrm{~mL} / \mathrm{h}, 25 \mathrm{~mL} / \mathrm{h}$ および $50 \mathrm{~mL} / \mathrm{h}$ と し, オクルーダを用いない従来の $0 \mathrm{kPa}$ との流 量変化を比較した. $50 \mathrm{~mL} / \mathrm{h}$ は中間流量の 2 倍 の設定流量であることから，より大きい変動を 確認できる可能性があり，また $10 \mathrm{~mL} / \mathrm{h}$ は高 圧酸素治療時の輸液ポンプの流量精度評価に用 いられており ${ }^{13)}$ ，JISにおける小児用への適用 の低流量とされていることから評価の対象とし た ${ }^{12)}$.

\section{3. 結 果}

\section{1 ) チューブ内圧測定装置の試作と評価}

予備実験の結果から，ロードセルの出力電圧 $V[\mathrm{mV}]$, オフセット $b[\mathrm{~Pa}]$ とし，2）式よりト ノメトリ式圧力計の圧力值 $P[\mathrm{~Pa}]$ が算出される ことを確認している.

$P=215.09 V+b$

トノメトリ式圧力計と圧力トランスデューサ で測定したチューブ内圧值の実験結果を図 3 に 示す. 図はトノメトリ式圧力計出力と圧力トラ ンスデューサ出力との相関関係を表したグラフ である. 両者の出力は $1 \mathrm{kHz}$ で 38,700 ポイン トサンプリングした。両者の相関係数を求める と $r=0.9988$ であった. 


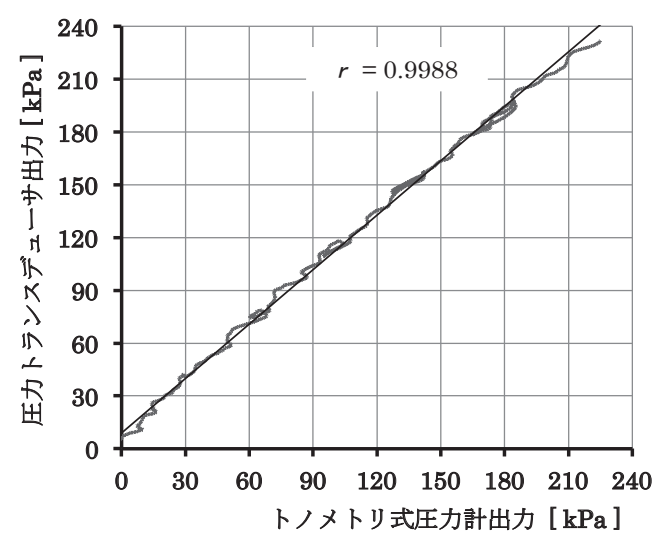

図3 圧カトランスデューサと試作 トノメトリ圧力計の相関

\section{2）圧閉度制御装置の試作と流量精度 の評価}

流量評価実験における最大内圧值の変化を 図 4 に示す。図の縦軸はトノメトリ式圧力計で 測定したチューブ内圧を示し，横軸は測定時間 を示した．また，值は 10 分〜120 分までの 330 ポイントをサンプルリングし, 平均と $95 \%$ の信 頼区間を算出した。最大内圧值 $150 \mathrm{kPa}$ の場合 $150.26 \pm 0.09 \mathrm{kPa}$ であり, $280 \mathrm{kPa}$ では $282.70 \pm$ $0.58 \mathrm{kPa}$ ，さらに $300 \mathrm{kPa}$ では $303.41 \pm 0.50 \mathrm{kPa}$ であった。測定時間約 $30 \mathrm{~min}$ で最大内圧值が 制御值 $\pm 4 \%$ に収束した。

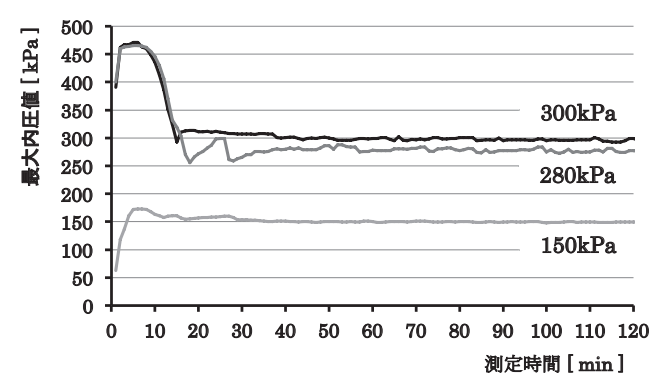

図4最大内圧值の変化

最大内压值を $300 \mathrm{kPa}, 290 \mathrm{kPa}, 220 \mathrm{kPa}$, $140 \mathrm{kPa}$ および $0 \mathrm{kPa}$ に設定した場合の流量 変化の実験結果を図 5 に示す。 5 条件の実験開 始時の気温は $26.7 \pm 0.9{ }^{\circ} \mathrm{C}$, 湿度は $29.4 \pm$ $4.7 \%$ \%゙った。図は実測值を 37 デー夕の移 動平均したグラフである. 最大内圧值 $300 \mathrm{kPa}$, $290 \mathrm{kPa}, 220 \mathrm{kPa}, 140 \mathrm{kPa}$ および $0 \mathrm{kPa}$ にお ける 6 時間後の流量減少量は, それぞれ $0.61 \mathrm{~mL} / \mathrm{h}(2.42 \%), 0.29 \mathrm{~mL} / \mathrm{h}(1.15 \%)$,

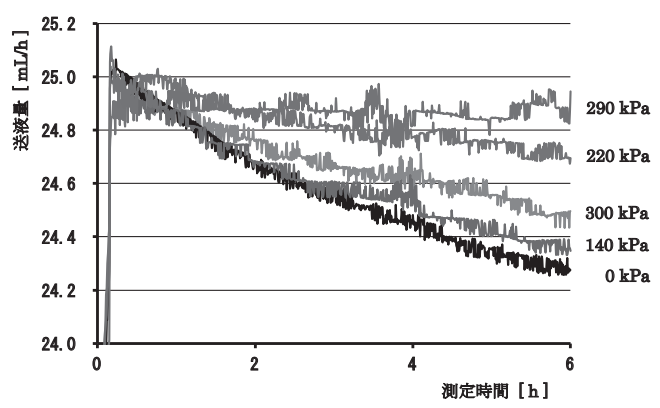

図5 最大内圧値を変化させた場合の流量 の変化

$0.36 \mathrm{~mL} / \mathrm{h}(1.42 \%), 0.70 \mathrm{~mL} / \mathrm{h}(2.80 \%)$, および $0.81 \mathrm{~mL} / \mathrm{h}(3.24 \%)$ であり, 従来の 0 $\mathrm{kPa}$ における流量減少量と比べ，いずれの最大 内圧值でも流量減少量は少なかった。特に流量 減少量が少なかったのは最大内圧值 $290 \mathrm{kPa}$ と $220 \mathrm{kPa}$ の場合であった。図 6 に最大内圧值と 6 時間後の流量減少量を示す.

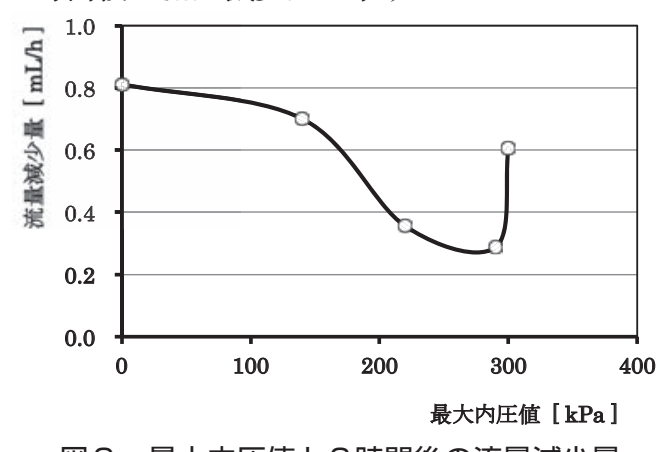

図6 最大内圧値と6 時間後の流量減少量

輸液ポンプの設定流量 $10 \mathrm{~mL} / \mathrm{h}, 25 \mathrm{~mL} / \mathrm{h}$ お よび $50 \mathrm{~mL} / \mathrm{h}$ において 12 時間連続使用によ る流量変化の実験結果を図 7 に示す. 6 回 の実験開始時の気温は $21.9 \pm 0.9{ }^{\circ} \mathrm{C}$, 湿度は $28.8 \pm 5.9 \%$ であった. 図の conventional は従

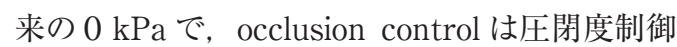
装置を用いて最大内圧 $290 \mathrm{kPa}$ とした場合の 流量変化である。図 7 における設定流量ごと の流量減少量および流量変化率を図 8 に示す. 図の横軸は輸液ポンプの設定流量, 縦軸は流量 減少量を示す。また, 棒グラフの左は従来の 0 $\mathrm{kPa}$ で, 右の斜線は圧閉度制御装置を用いた場 合である．設定流量 $10 \mathrm{~mL} / \mathrm{h}, 25 \mathrm{~mL} / \mathrm{h}$ および $50 \mathrm{~mL} / \mathrm{h}$ における従来の $0 \mathrm{kPa}$ の流量減少量 は $0.63 \mathrm{~mL} / \mathrm{h}(6.27 \%), 1.14 \mathrm{~mL} / \mathrm{h}(4.56 \%)$ および $2.01 \mathrm{~mL} / \mathrm{h}(4.01 \%)$ であった。また, 


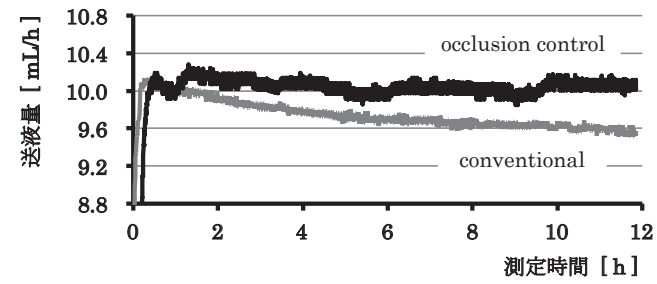

a) 設定流量 $10 \mathrm{~mL} / \mathrm{h}$

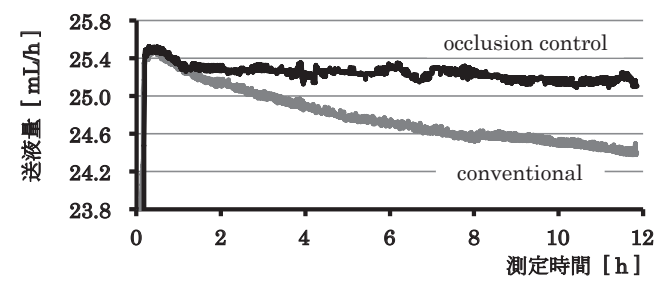

b）設定流量 $25 \mathrm{~mL} / \mathrm{h}$

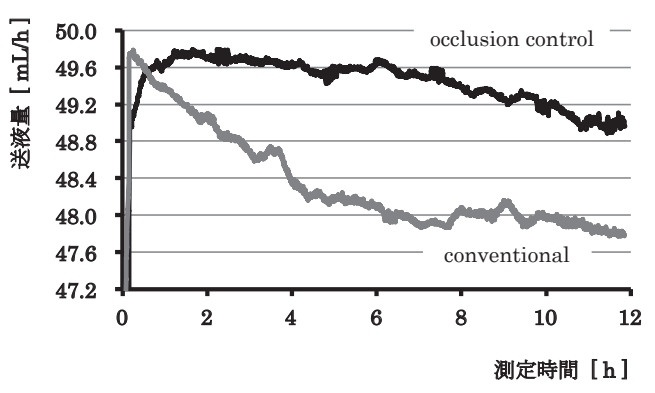

c) 設定流量 $50 \mathrm{~mL} / \mathrm{h}$

図7 12 時間連続使用による流量変化

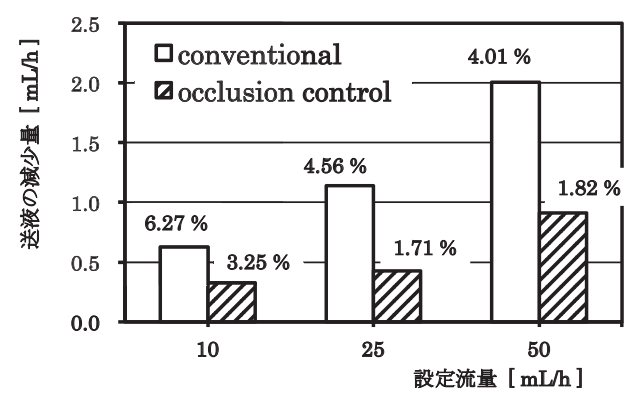

図8 設定流量の違いによる流量減少量 と流量変化率

設定流量 $10 \mathrm{~mL} / \mathrm{h}, 25 \mathrm{~mL} / \mathrm{h}$ および $50 \mathrm{~mL} / \mathrm{h}$ に打ける最大内圧 $290 \mathrm{kPa}$ の流量減少量は $0.32 \mathrm{~mL} / \mathrm{h}(3.25 \%), 0.43 \mathrm{~mL} / \mathrm{h}(1.71 \%)$ およ び $0.91 \mathrm{~mL} / \mathrm{h} （ 1.82 \%)$ であった。流量減少量 の差は $0 \mathrm{kPa}$ の場合と比較し, $10 \mathrm{~mL} / \mathrm{h}$ では $0.30 \mathrm{~mL} / \mathrm{h}, 25 \mathrm{~mL} / \mathrm{h}$ では $0.71 \mathrm{~mL} / \mathrm{h}, \quad 50 \mathrm{~mL} / \mathrm{h}$ では $1.10 \mathrm{~mL} / \mathrm{h}$ である.

\section{4. 考察}

\section{1 ）チューブ内圧測定装置の試作と評価}

容積制御方式輸液ポンプのチューブ内圧を上 昇させ, チューブ内径を拡張させることでチュー ブ復元力の回復を促す装置を考案した。この装 置は従来の輸液ポンプに組み込まれていない, 精度の高い圧力計とチューブ圧閉度制御するオ クルーダが必要である。そこで, トノメトリ式 圧力計を試作し, 評価した。トノメリ式圧力 計と圧力トランスデューサで測定したチューブ 内圧の相関関係を確認した。 その結果, 相関係 数が $r=0.9988$ であった. トノメトリ式圧力計 は圧力トランスデューサと同様にかつ, 液体に 非接触でチューブ内圧測定が可能であることが 示された。

\section{2）圧閉度制御装置の試作と流量精度 の評価}

圧閉度制御装置はトノメトリ式圧力計とオ クルーダで構成される。オクルーダはチュー ブの流路抵抗を増加させることでチューブ内 圧を上昇させることを目的とした装置であ る. 最大内圧值の $95 \%$ の信頼区間は最大内 圧值 $150 \mathrm{kPa}$ の場合 $150.26 \pm 0.09 \mathrm{kPa}$ であり, $280 \mathrm{kPa}$ で $282.70 \pm 0.58 \mathrm{kPa}$, さらに $300 \mathrm{kPa}$ で は $303.41 \pm 0.50 \mathrm{kPa}$ であった。いずれの最大 内圧值に抒いても， $30 \mathrm{~min}$ 以内に $\pm 4 \%$ に収 束していることから圧閉度制御装置が良好に機 能していることが確認できた.

流量精度評価において最良となる最大内圧值 の範囲を決定するため, 最大内圧值を $140 \mathrm{kPa}$, $220 \mathrm{kPa}, 290 \mathrm{kPa}$ および $300 \mathrm{kPa}$ で流量精度評 価を抢こなった。その結果, 最大内圧值が $220 \mathrm{kPa}$ および $290 \mathrm{kPa}$ で特に流量減少量が小 さくなった．最大内圧值を増加させることでチ ユーブ断面が拡張され, 復元力が維持されたも のと思われる. しかし, 最大内圧值 $290 \mathrm{kPa}$ りも $300 \mathrm{kPa}$ の方が, 流量減少量が増加した. これは輸液ポンプのフィンガ部の上部で輸液バ ック側への液の逆流が発生したと考えられる. 以上のことから, 最大内圧值は $220 \sim 290 \mathrm{kPa}$ が最良で, $300 \mathrm{kPa}$ 以上にしないことが必要で ある。 
最大内圧值 $290 \mathrm{kPa}$ と従来の $0 \mathrm{kPa}$ において 12 時間の連続流量計測をおこなった。輸液ポ ンプの設定流量 $10 \mathrm{~mL} / \mathrm{h}, 25 \mathrm{~mL} / \mathrm{h}$ および $50 \mathrm{~mL} / \mathrm{h}$ において従来の $0 \mathrm{kPa}$ と最大内压值 $290 \mathrm{kPa}$ の流量減少量を比較した結果, 圧閉度 制御をおこなった場合の流量減少量が少なか った。 よって, 従来の装置よりも本装置を用 いた場合で流量減少量を改善することが確認 できた。また，図 8 より設定流量 $10 \mathrm{~mL} / \mathrm{h}$, $25 \mathrm{~mL} / \mathrm{h}$ および $50 \mathrm{~mL} / \mathrm{h}$ における, 最大内圧 值 $290 \mathrm{kPa}$ における流量減少量はそれぞれ, $0.32 \mathrm{~mL} / \mathrm{h}(3.25 \%), 0.43 \mathrm{~mL} / \mathrm{h}(1.71 \%)$ およ び $0.91 \mathrm{~mL} / \mathrm{h} （ 1.82 \%)$ であり低流量において 流量減少量は少なく, 中間流量において減少 率が小さくなる結果であった。輸液セットは 軟質の塩化ビニールで形成されており, 高分 子材料の変形では粘弾性を考慮する必要があ る。粘弾性素材はひずみが直ちに最終值に達す るのではなく徐々に近づく（遅延弾性）現象が あり ${ }^{14,15)}$, チューブを変形させる回数や変形時 間が効果に影響していると考えられる.

ペリスタルティック方式輸液ポンプの流量誤 差範囲は, $\pm 10 \%$ 以内とされており，小児の 輸液療法など, 低流量における薬剤投与には向 いていないとされている，また，容積制御方式 輸液ポンプはチューブ復元力の低下により薬液 が残る問題があり, 輸液ポンプを長時間用いる 場合には 24 時間おきに, チューブの装着位置 をずらすか, 新しい製品と交換することとチュー ブの製品仕様に記載がある ${ }^{16)}$ 。この作業は臨床 現場において看護師がおこなっており, IVH で 24 時間キープの患者の輸液交換が他の処置 に追われ，現場に行くのが遅くなり空になった などの看護師の作業量の増加や医療事故の原因 にもなっている ${ }^{1)}$. 輸液ポンプを 12 時間連続使 用した結果，圧閉度制御装置を使用した場合， 小児用への適用の低流量である設定流量 $10 \mathrm{~mL} / \mathrm{h}$ で, 従来の $0 \mathrm{kPa}$ と比較した場合, $0.30 \mathrm{~mL} / \mathrm{h}$ 流量減少が少なかった. 設定流量 $25 \mathrm{~mL} / \mathrm{h}$ および $50 \mathrm{~mL} / \mathrm{h}$ の比較においても, $0.71 \mathrm{~mL} / \mathrm{h}$ および $1.10 \mathrm{~mL} / \mathrm{h}$ 流量減少が少なか った，以上のことから，圧閉度制御装置は小览 輸液療法へ応用範囲が広がり, チューブ位置変
更の作業が減り，看護師の作業軽減および誤操 作の防止などが期待できる.

現在市販されている輸液ポンプの中には，チ ューブを完全には圧閉しないミッドプレス方式 や ${ }^{17)}$ ，ほぼ $90^{\circ}$ 異なる方向から送液チューブを 交互に押圧するX -プレス方式など ${ }^{18)}$ ，チュー ブ変形を防止する圧閉機構を備えたものがあ る.これらの方式との流量精度差は今後検討す る必要がある。また，輸液開始直後に送液流量 の立ち上がりが遅いことが問題と考えられる. この点については最大内圧值が設定值になるま でポンプを早送りするなどの方法を今後検討す る必要がある。

\section{5. 結 論}

容積制御方式輸液ポンプのチューブ復元力の 回復を促すため, チューブ内圧を上昇させ，チ ユーブ内径を拡張させる機構を組み込んだ輸液 ポンプを考案した，考案した機構を達成するた め, トノメトリ法を用いた圧力計とチューブ内 圧の上昇のためのオクルーダを試作した.

最大内圧值を変化させた場合の流量低下が最 小となる最大内圧值の範囲は $220 \sim 290 \mathrm{kPa}$ が最良で, $300 \mathrm{kPa}$ 以上にしないことが必要 であることが示された。また 12 時間連続使 用では，設定流量 $10 \mathrm{~mL} / \mathrm{h}, 25 \mathrm{~mL} / \mathrm{h}$ および $50 \mathrm{~mL} / \mathrm{h}$ における従来の $0 \mathrm{kPa}$ と最大内圧值 $290 \mathrm{kPa}$ の流量減少量の比較をすると, $0.30 \mathrm{~mL} / \mathrm{h}, \quad 0.71 \mathrm{~mL} / \mathrm{h}$ および $1.10 \mathrm{~mL} / \mathrm{h}$ の改善 が示された。 よって，チューブ内圧を上昇さ せ，チューブ内径を拡張させる機構を組み込ん だ輸液ポンプを用いることで，チューブ復元力 の回復を促し, 流量減少量が少ない容積制御方 式輸液ポンプが実現できることが示された.

\section{文献}

1）小野沢康子, 吉岡菜緒美, 神林政子ほか. 臨 床看護の場に打けるインシデントの実態と発 生要因の検討. 新潟県立看護短期大学紀要. 2000, vol. 6 , p. $71-90$.

2 ) 深澤敏彌, 羽柴正夫, 下地恒毅. 輸液ポンプ 使用上の問題点. 医科器械学. 1990, Vol. 60, No. 6, p. 287 - 290. 
3 ) Dominic, F.; Ann, B.; Atish, R. et al. The visible and the invisible: Distributed Cognition for medical devices. 2011, EICS 4 Med, p. 1-6.

4 ）山本章博. 輸液ポンプ・シリンジポンプの医 療事故防止対策. Clinical Engineering. 2004, Vol. 15, No. 4, p. 403-409.

5 ）堀内邦雄. “輸液ポンプ”. ME の基礎知識と 安全管理（改訂第 5 版）日本生体医工学会 $\mathrm{ME}$ 技術教育委員会監修. 南江堂. 2008, p. 326 333.

6 ) Emma, J. G.; Mark, A. H.; Diana, W. Reliability of drop size from multi-dose eye drop bottles: is it cause for concern? Royal College of Ophthalmologists. 1999, Vol. 13, p. $93-100$.

7 ）梶原康平, 菅原俊継, 黒田 聡ほか. 輸液ポ ンプの流量誤差発生要因に関するアンケート 調查扮よび検証. 北海道工業大学研究紀要. 2008, Vol. 36, p. 209-213.

8 ）吉川浩一, 大澤純子, 根井さき子. 流量制御 方式の輸液ポンプにおける輸液セット装着手 技が流量誤差におよぼす影響. 日本医療マネ ジメント学会雑誌. 2006, Vol. 7, No. 3, p. 410 - 414 .

9）梶原康平，菅原俊継，黒田 聡ほか. 使用条 件の違いによる輸液ポンプにおける流量誤 差の検証. 電子情報通信学会. 2009, Vol. 108, p. $49-53$.

10）嶋津秀昭. “血圧計”。MEの基礎知識と安全 管理（改訂第 5 版）、日本生体医工学会 ME 技 術教育委員会監修. 南江堂. 2008, p. 158 -
168.

11) Jja-Jung, W.; Shtng-Hong, L; Ching-Iuan C. et al. Development of An Arterial Applanation Tonometer For Detecting Arterial Blood Pressure And Volume. Biomedical Engineering-applications, Basis \& Communications. 2004, Vol. 16, No. 6, p. 322-330.

12) 日本規格協会 (編) : 医用電気機器 - 第 $2-24$ 部: 輸液ポンプ及び輸液コントローラの安全に関 する個別要求事. JIS T 0601-2-24, 2005.

13) Hiroshi, D.; Kazuhiro, A.; Yuichi, K. Accuracy of a peristaltic finger-type infusion pump during hyperbaric oxygen therapy. Journal of Anesthesia. 2002, Vol. 16, No. 4, p. 294 297.

14）堀江一之, 白石振作. 合成および加工技術 材 料テクノロジー 16 ポリマー材料. 東京大学出 版, 1984, p. 51-112.

15）W・フリューゲ。“粘弾性模型”。固体の力学 シリーズ 粘弾性学. 培風館, 1973, p. 4-23.

16) テルモ(株)。医療機器承認番号 $21200 \mathrm{BZZ} 00088$ テルフュージョン ポンプ用輸血セット 添付文 書改定第 3 版. 2005, 2 p.

17）古澤康一、ミッドプレス方式による輸液ポン プの開発. Clinical Engineering. 1998, Vol. 9, No. 12, p. 1,134-1,140.

18）太田建三, 河本健一. 蠕動ポンプにおける送 液チューブ復元機構. 特許公報, 特許番号： 4353738, 2009. 